\title{
Feeding ecology of short-tailed shearwaters: breeding in Tasmania and foraging in the Antarctic?
}

\author{
Henri Weimerskirch*, Yves Cherel
}

CEBC - CNRS, F-79360 Beauvoir, France

\begin{abstract}
The food, feeding and physiological ecology of foraging were studied in the short-tailed shearwater Puffinus tenuirostris of Tasmania, to establish whether this species can rely on Antarctic food to fledge its chick. Parents were found to use a 2 -fold foraging strategy, on average performing 2 successive short trips at sea of 1 to $2 \mathrm{~d}$ duration followed by 1 long trip of 9 to $17 \mathrm{~d}$. These long foraging trips are the longest yet recorded for any seabird. During short trips the parents tend to lose mass, feeding the chick with Australian krill and fish larvae caught in coastal and neritic waters around Tasmania. The prey are caught at maximum diving depths of $13 \mathrm{~m}$ on average (maximum $30 \mathrm{~m}$ ). During long trips, adults gain mass and feed their chicks with a very rich mixture of stomach oil and digested food composed of a high diversity of prey including myctophid fish, sub-Antarctic krill and squids. Prey are probably caught mainly in the Polar Frontal Zone, at least $1000 \mathrm{~km}$ south of Tasmania, at maximum depths of $58 \mathrm{~m}$ on average (maximum $71 \mathrm{~m}$ ). Long foraging trips in distant southern waters gave at least twice the yield of trips in close waters but during the former, yield decreased with the time spent foraging, as indicated by the inverse relationship between time spent foraging and adult body condition. Decisions whether to forage in close or distant waters appear to be determined by the body condition

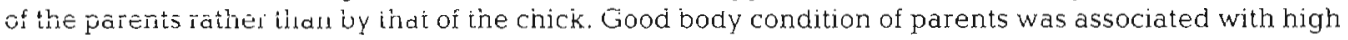
blood prolactin levels: birds in poor body condition invested in the restoration of body reserves and went to the rich area of the Polar Frontal Zone or to Antarctic waters, whereas those in good condition continued to provision the chick with food caught in Tasmanian waters and use their body reserves. The species thus exploits 2 water masses that differ in profitability. Most of the energy budget for rearing the chick is balanced by prey caught in rich southern waters where the birds build up their body reserves and find most of the energy needed by the chick. However, nearby shallow waters are important for the breeding strategy as they allow an increased rate of energy flow to the chick. In a species as abundant as the short-tailed shearwater, the 2-fold strategy has the advantage of limiting competition in coastal and shallow waters, as at any one time only $17 \%$ of birds are feeding there. The influence of the marine environment and energetic constraints on the evolution of provisioning strategies is discussed.
\end{abstract}

KEY WORDS: Allocation - Energy gain · Foraging efficiency - Chick growth - Antarctica - Diving depths $\cdot$ Resource partitioning Seabirds - Puffinus tenuirostris

\section{INTRODUCTION}

Marine animals show specific breeding strategies arising from the distinctive characteristics of the marine environment (Ashmole 1971, Ricklefs 1990). For example the major constraint on breeding for seabirds is the distance between the breeding grounds on land and the feeding zones at sea. Procellariiformes

•E-mail: henriw@cebc.cnrs.fr (albatrosses and petrels) are able to rely on distant resources because of specific adaptations, for example the reduction of flight energy costs through morphological adaptations (Pennycuick 1981) and the ability to concentrate energy into stomach oil (Warham 1996). However, distances that can be travelled between breeding and feeding zones are limited by the constraints imposed by the needs to incubate the egg and rear the chick. During rearing they have to provision the chick regularly to cover its energetic requirements for maintenance and growth. As a result, foraging 
range is generally shorter during the chick rearing period than during incubation (Weimerskirch 1997). The second constraint on the evolution of long-distance foraging is the availability of food in potential feeding zones, which determines whether enough food can be found to fulfil the needs of the chicks as well as to cover the costs of foraging. Therefore a trade-off exists between distance to the feeding zone and availability of food there, which has probably led to specific foraging and provisioning strategies related to the particular marine environment exploited (Weimerskirch et al. 1997, Weimerskirch 1998).

Short-tailed shearwaters Puffinus tenuirostris breed in huge numbers around Tasmania (Skira et al. 1985) and are observed feeding in large flocks during the nesting season in the surrounding coastal and offshore waters (Marchant \& Higgins 1990). The feeding frequency observed in this species when on its Tasmanian breeding grounds and the prevalence of Australian krill in its diet have led previous authors to the conclusion that short-tailed shearwaters rear the chick using food resources found close to the breeding grounds (Bishop et al. 1983, Montague et al. 1986, Skira 1986, Oka et al. 1987). They provision their chick cyclically and it has been suggested that these cycles are related to lunar phases that influence the availability of prey (Oka et al. 1987). At the time when they are rearing chicks in Tasmania, large numbers of short-tailed shearwaters are present in Antarctic waters (Woehler et al. 1990, Veit \& Hunt 1991), $2000 \mathrm{~km}$ from the colonies. The status of the birds observed in Antarctica is not known but they have generally been considered as non-breeders, although some breeding birds may be present (Naarding 1980, Kerry et al. 1983). However, Weimerskirch (1998) showed that the closely related sooty shearwater Puffinus griseus uses a 2 -fold foraging strategy to provision its chick whereby it forages alternatively in close coastal waters and in distant waters. He suggested that short-tailed shearwaters breeding in Tasmania could be able to feed as far distant as the Antarctic by using a similar 2-fold strategy and that the cyclic colony attendance observed by Oka et al. (1987) would be the consequence of this strategy and have nothing to do with feeding conditions at sea.

Previous workers studying short-tailed shearwaters have deduced potential foraging range from average feeding frequencies, but these do not allow determination of the duration of individual foraging trips, and the diet samples were collected from birds returning from the sea after foraging trips of unknown duration. The aims of this study were to (1) investigate whether birds breeding in Tasmania are able to feed their chick with food from Antarctica, (2) explain the cyclic attendance observed in this species and (3) examine the physiological and ecological trade-offs relating to foraging decisions. To do this we have studied for the first time, by continuously monitoring a colony, the individual provisioning behaviour of parent short-tailed shearwaters, and the diet and diving behaviour of individuals during foraging trips of known duration. The study of the diet allowed us to determine the water masses where prey was caught and thus to deduce minimum distances between the feeding and breeding zones. In addition, the roles of parent and offspring in determining foraging behaviour were studied by monitoring body condition and hormonal and metabolite levels of adults.

\section{METHODS}

Field study. The study was carried out at The Neck Game Reserve, Bruny Island $\left(43.3^{\circ} \mathrm{S}, 147.3^{\circ} \mathrm{E}\right)$, Tasmania, between 20 and 27 January and between 1 and 27 March 1997. A total of 89 burrows were monitored to determine hatching dates, growth of the chicks and attendance patterns of adults. In January burrows were monitored during the day and once at night to determine the presence of an egg or of a chick, to measure the chicks, and to measure and band parents. Hatching dates were estimated from the proportion of nests with eggs and chicks between 20 and 27 January, and for the chicks hatched before 20 January, from their body mass on 20 January and the growth equation for short-tailed shearwaters given by Oka (1989).

The lengths of culmen, head (from tip of beak to back of skull), tarsus and wing of adults were measured to the nearest $0.1 \mathrm{~mm}$ using a caliper and a ruler (wing). To estimate body size we used the factor score computed from the first principal component of the measurements of the culmen, head, foot and wing lengths using a principal component analysis (Freeman \& Jackson 1990). Measurements were taken for at least 1 parent of each pair. For pairs where both adults were measured, we considered that within a pair, the larger bird was the male (Marchant \& Higgins 1990). For other pairs, the sex of birds was estimated with a discriminant analysis based on birds of known sex. Body condition of adults was defined as the residual from the linear regression of body mass on body size.

For most burrows, the nesting chamber was accessible from the natural mouth of the burrow, but in long burrows, a window was dug out to give access to the chamber. In March, sticks were placed at the mouth of the burrow, so that a visit by an adult could be detected by displacement of the sticks. Burrows were inspected every half hour from dusk (sunset between 18:30 and 19:00 h local time during the study period) to midnight, but also during an inspection $1 \mathrm{~h}$ before dawn, and during the day at 17:00 h. During the day inspection. 
chicks were weighed to the nearest $10 \mathrm{~g}$ with a Salter spring balance. During the night, if a visit was detected the adult was caught when the chick had ceased begging, i.e. when feeding had stopped and the adult was about to return to sea; otherwise if the chick was still begging a repeat inspection was made to the burrow at the end of the round tour. At every capture the parents were identified by their bands and weighed to the nearest $10 \mathrm{~g}$. The chick was weighed each time that an adult had visited the nest. A significant proportion of adults visiting the chick after midnight stayed near the burrow after they had delivered the meal and left the colony en masse at dawn. These birds were recaptured during the pre-dawn inspection. The body condition of chicks was defined as the residual from the linear regression of body mass upon date.

The duration of individual foraging trips was defined as the time elapsed between 2 successive recoveries of the same bird. As about $28 \%$ of the birds were missed during recapture sessions, all trips of uncertain duration were excluded from the analysis. However, because the distribution of the duration of the foraging trips was clearly bimodal, with no trips of 4 to $8 \mathrm{~d}$, we calculated the duration of certain trips by assuming that there were no trips of 5 to $7 \mathrm{~d}$. Meal mass was calculated as the difference in body mass of the chick between the 17:00 h weighing and that recorded after a visit by a parent. When 2 parents had fer the chick between 2 burrow inspections, the increase of mass corresponding to the double feed was not used in the calculations of meal mass.

Because poachers took chicks from our burrows at different stages, but especially at the end of the study period, of the 89 burrows initially studied, we were able to follow only 49 burrows over at least 17 successive days. To study growth curves and chick condition, we used a sub-sample of 25 chicks. The 24 other chicks were excluded from this analysis because at least 1 of their parents was caught before or during food delivery to the chick, and thus possibly not all the food was delivered, introducing a possible bias. In these cases meal mass, and body mass of adults, were not used.

The study period in March encompassed a complete lunar cycle. Data on weather conditions were provided by the meteorological station of South Bruny. To study the influence of meteorological factors on the number of birds visiting the colony each night, we used average and maximum wind speeds over the $12 \mathrm{~h}$ preceding the first arrival at the colony at 19:00 h, and barometric pressure at noon before the first arrival.

Diving depths. A total of 36 adult birds were fitted with capillary tubes attached to the back feathers using a waterproof adhesive tape. The tubes were $120 \mathrm{~mm}$ long, made of PVC tubing of $0.8 \mathrm{~mm}$ internal diameter (Tygon Tubing, Cole Parmer, Noles, IL, USA) lined with soluble indicator powder and heat-sealed at one end (Burger \& Wilson 1988). Birds were recaptured after 1 foraging trip at sea. In all, 22 tubes were recovered after foraging trips of 1 to $14 \mathrm{~d}$. Methods and the equation used to calculate maximum depth attained are described by Burger \& Wilson (1988).

Diet and energy flow. Food samples were obtained using the 'water off-loading technique' (Wilson 1984) or through spontaneous regurgitation of adult shearwaters on arrival back at the colony after a foraging trip, before they fed their chick. Seventeen food samples were collected from birds returning after a long trip at sea, and only 5 after a short trip, because poaching occurred when most of the birds were performing long trips, thus precluding the collection of more samples after short trips. Stomach contents were returned deepfrozen $\left(-20^{\circ} \mathrm{C}\right)$ to the laboratory in France for analysis. Each sample was thawed and drained by gravity for $16 \mathrm{~h}$ to separate oil and water from the solid fraction. The volume of oil was then measured in a graduated tube. Accumulated items (squid beaks, squid and fish lenses) and fresh items were analysed separately. Each different item was numbered and identified to the lowest possible taxon, using published keys (Clarke 1986, Baker et al. 1990, Smale et al. 1995, Vinogradov et al. 1996) and our own reference collection.

Energy flow and energetic yield of foraging trips were estimated following Weimerskirch ct al. (1097). The energy flow is the average quantity of energy received by the chick per unit of time, i.e. twice (2 parents) the mass of the meal multiplied by its calorific value per unit of time. The calorific value of meals is the energy equivalent of each component, with values in $\mathrm{kJ} \mathrm{g}^{-1}$ (wet weight) of 4.35 for crustaceans (Croxall et al. 1985), 5.61 for fish (Clarke \& Prince 1980), 7.0 for myctophid fish (Cherel \& Ridoux 1992) and 42.2 for stomach oil (Warham et al. 1976). The energetic equivalent of change in adult mass is $22.3 \mathrm{~kJ} \mathrm{~g}$ assuming that the material lost is mainly lipid but also protein (Groscolas et al, 1991). The assimilation coefficient is 0.76 (Jackson 1986) and the cost of storing energy one third of the accumulated energy (Ricklefs et al. 1980). The energy expenditure at sea for short-tailed shearwaters was estimated using a regression of log body mass against field metabolic rates estimated for petrels and albatrosses (excluding storm petrels and diving petrels which have different flight energetics, and hence mass-specific energy expenditure; Pennycuick 1989). Values used were those summarised by BirtFriesen et al. (1989), giving for a short-tailed shearwater with a mass of 570 to $590 \mathrm{~g}$ an energy expenditure of $1.45 \mathrm{~kJ} \mathrm{~d}^{-1} \mathrm{~g}^{-1}$.

Prolactin and metabolite assays. Blood was obtained within 2 to 3 min after capture of adult birds returning from the sea. A blood sample of 1 to $2 \mathrm{ml}$ was taken 
from a wing vein with a heparinized syringe, kept at $+5^{\circ} \mathrm{C}$ in crushed ice, centrifuged and the plasma stored at $-20^{\circ} \mathrm{C}$ until assayed. Prolactin was assayed by radioimmunoassay according to Cherel et al. (1994). All plasma samples were measured in duplicate at the same time to eliminate inter-assay variation. Pooled plasma samples of short-tailed shearwaters produced a dose-response curve that paralleled the chicken prolactin standard curve (data not shown). Plasma uric acid and $\beta$-hydroxybutyrate were measured using kits provided by Bio-Mérieux (Lyon, France, PAP 150) and Sigma Diagnostics (St. Louis, MO, USA, Procedure No. 310-UV), respectively.

Foraging zones and ranges. The positions of fronts delimiting the different water masses were estimated from weekly maps of sea surface temperatures (SST) (Reynolds \& Smith 1994) for the first 2 wk of March following the definition of the fronts and zones derived from SST given by Lutjerhams \& Valentine (1984) and Rintoul et al. (1997). Maximum foraging ranges were estimated assuming that birds fly continuously in a
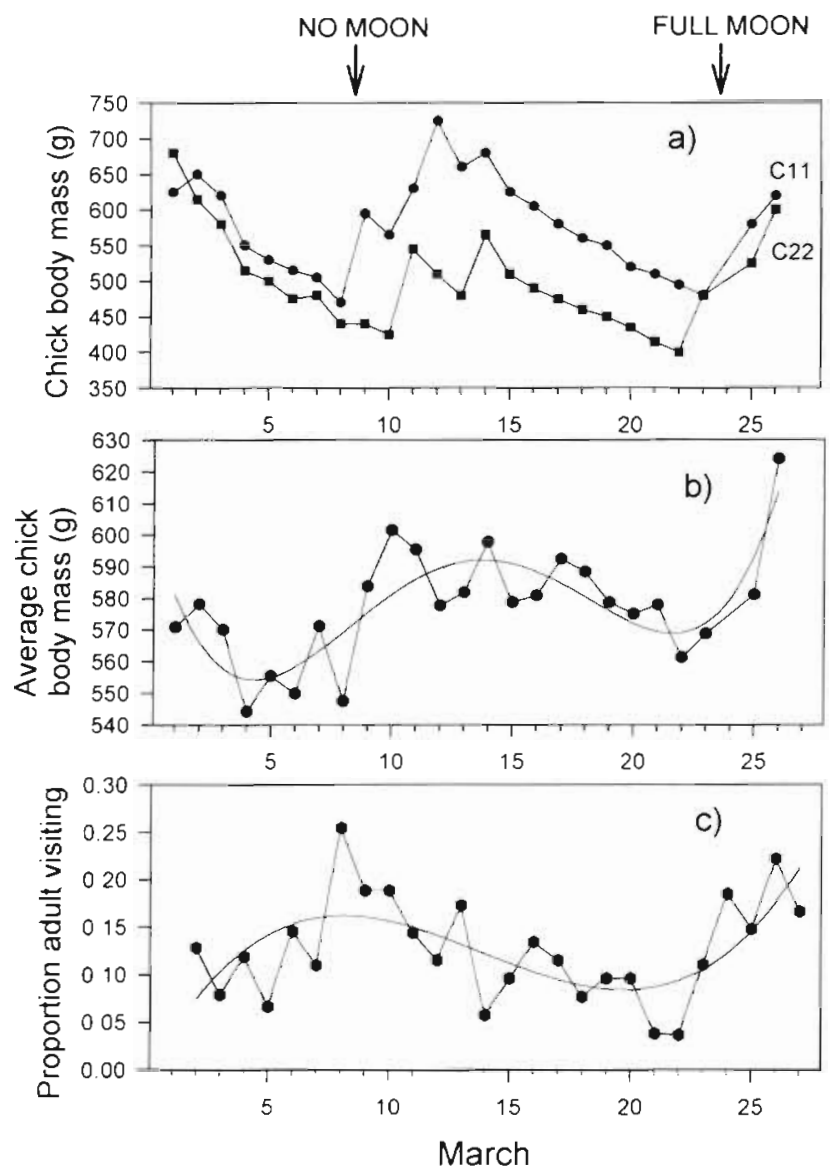

Fig. 1. Puffinus tenuirostris. Changes between 1 and 25 March 1997 (a) in the body mass of 2 individual chicks, (b) in the average body mass of 25 chicks, and (c) in the proportion of adult parents visiting their chicks in 63 burrows straight line to the feeding zone during the foraging trip, with average flight speeds of $28 \mathrm{~km} \mathrm{~h}^{-1}$ (calculated from Pennycuick 1989) and time spent moving being half the duration of foraging trips.

Statistics. Data were analysed using SYSTAT 6.0 (Wilkinson 1996).

\section{RESULTS}

\section{Chick growth and colony attendance}

On 20 January, $82.7 \%$ of the nests contained a hatched chick and the remainder eggs. Hatching was estimated to take place between 8 and 24 January 1997, with most hatching occurring on 16 January. In January chicks tended to be fed every day by at least 1 adult, as chicks were always attended by an adult at night. The average mass of chicks was $138.5 \pm 44.2 \mathrm{~g}$ ( $\mathrm{n}=48$ ) on 20 January when $64.5 \%$ of chicks were attended by an adult during the daytime. On 27 January, when all chicks were left alone during the daytime, their average body mass was $221.2 \pm 68.9 \mathrm{~g}(\mathrm{n}=53)$.

In March chicks were fed infrequently, and their body mass showed a succession of long periods of fasting and periods of mass gain (Fig. 1a). There was an overall increase in the average mass of chicks ( $\mathrm{r}=$ $0.439, p=0.02$ ), but the change in body mass over time tended to follow a cycle whose lowest values were ca $16 \mathrm{~d}$ apart (Fig. 1b). Over the study period, the average number of feeds received by the chick per day was 0.258 (range 0.074 to 0.379 ), i.e. on average a chick received a meal every $3.9 \mathrm{~d}$, suggesting that the average foraging trip of each parent was $7.8 \mathrm{~d}$. The distribution of intervals between feeds indicates that chicks can fast up to $15 \mathrm{~d}$ without being fed, but that intervals of 1 and $2 \mathrm{~d}$ were overrepresented (Fig. 2).

The number of adult birds visiting the chick varied significantly from one day to the next over the study period $\left(\chi_{26}^{2}=52.7, p<0.001\right)$, with 3.7 to $25.5 \%$ of adults visiting the chick each day (Fig. 1c). The proportion of parents visiting the chick on a particular day was not related to lunar phase $(r=0.117, n=27, p>$ $0.1)$, barometric pressure $(r=0.236, p>0.1)$, average wind speed $(r=0.175, p>0.1)$ or wind direction $(r=$ $0.0331, p>0.1$ ). Adults returned from foraging trips throughout the night. However $43.1 \%$ of the parents returned during the first hour after sunset, $26.3 \%$ during the next $3 \mathrm{~h}$ and $31.6 \%$ from midnight to dawn.

\section{Foraging trips}

The distribution of the duration of individual foraging trips was bimodal, with no trips lasting between 4 


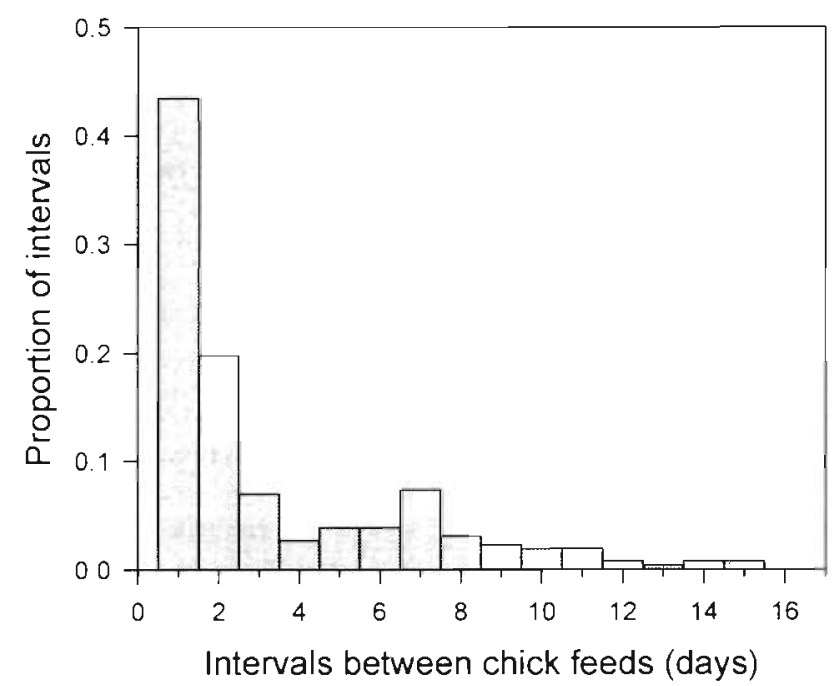

Fig. 2. Puffinus tenuirostris. Distribution of intervals between feeds received by chicks of short-tailed shearwaters

and $8 \mathrm{~d}$ (Fig. 3a). Foraging trips lasting 1 to $3 \mathrm{~d}$ are denoted short trips (ST), and those of 9 to $17 \mathrm{~d}$ or more, long trips (LT). The distribution of the duration of foraging trips was similar for males and females for ST (G-test, $G=0.706, \mathrm{p}=0.702)$ and for LT $(G=7.7, \mathrm{p}=$ $0.176)$. There was no significant difference in the timing of arrival between the number of birds returning from ST and LT $\left(\chi_{2}^{2}=0.621, p=0.733\right)$.

There were 87 records of birds returning from a LT and $75.8 \%$ of them then started a ST while the others started a new LT. Of 33 birds returning from a first ST $60.6 \%$ started a second ST. After a second ST, only $6.2 \%$ of 18 birds started a third ST, and all the birds returning from a third ST started a LT. The general pattern of foraging trips was therefore a LT followed by $2 \mathrm{ST}$, and then another LT.

\section{Meal mass}

The average mass of feeds delivered to the chick was $124.4 \pm 56.5 \mathrm{~g}$ (range 10 to $220, \mathrm{n}=134$ ), but the distribution of meals was bimodal (Fig. 3b). Meals delivered after LT were significantly heavier than after ST (Table 1). The mass of meals delivered after a ST was similar for foraging trips of 1 and $2 \mathrm{~d}$ duration (76.9 \pm $40.7, \mathrm{n}=39$, range 10 to 175 , and $73.8 \pm 27.6, \mathrm{n}=17$, range 40 to 130 respectively; $p=0.770$; Fig. 4 a) and was not influenced by whether it was a first or a second ST $(75.0 \pm 32.6, n=19$, range 30 to 175 , and $87.0 \pm 38.9$, $\mathrm{n}=10$, range 45 to 145 , respectively; $\mathrm{p}=0.386$ ). For $\mathrm{LT}$ there was no significant relationship between the duration of the foraging trip and the meal size ( $\mathrm{r}=$ $-0.181, \mathrm{n}=17, \mathrm{p}>0.1$ ).
There was a significant relationship between the mass of the meal delivered and the condition of the chick ( $r=-0.716, n=98, p<0.0001)$. This was the result of chicks being in low condition when the parent returned from a $\mathrm{LT}$, and a better condition when just fed after a ST. To overcome this bias, we separated ST from LT. The condition of the chick did not influence the mass of the meal delivered after a ST $(r=-0.082$, $\mathrm{n}=45, \mathrm{p}>0.1)$ or after $\mathrm{a} \operatorname{LT}(\mathrm{r}=-0.337, \mathrm{n}=12, \mathrm{p}>0.1)$. The condition of the chick had no influence on the duration of the next foraging trip after a ST $(r=0.0387$, $n=56, p>0.1)$ or after a LT $(r=0.062, n=44, p>0.1)$

\section{Adult mass and body condition}

Although there was no relationship between the mass of adults and the date $(r=-0.101, n=98, p>0.1)$ there was a tendency for adult body condition to decline over the study period $(\mathrm{r}=-0.219, \mathrm{n}=76, \mathrm{p}=$ 0.06 ). When they arrived at the colony the body mass of adults was higher after a LT than after a ST (Table 1). This was mainly due to the fact that meals were larger after LT than after ST: indeed although adults were slightly heavier after delivering a meal following a LT compared to after a ST, their body condition was similar (Table 1). Adult mass changed from one trip to the
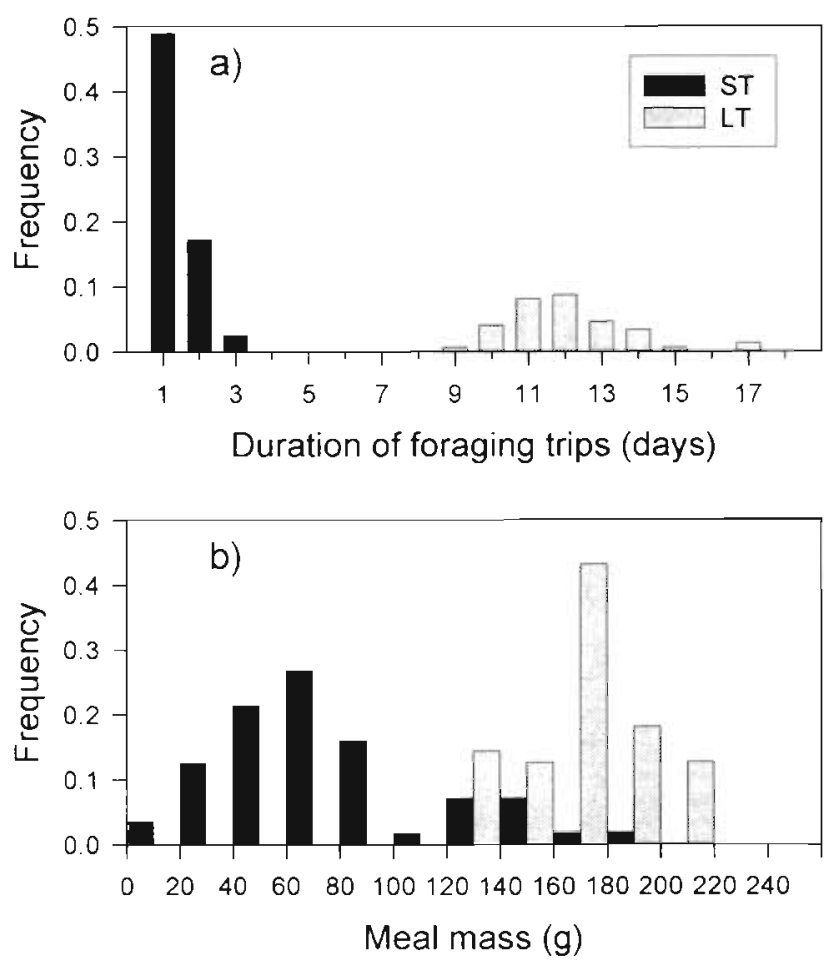

Fig. 3. Puffinus tenuirostris. Distribution (a) of the duration of foraging trips and (b) of the meal mass of short-tailed shearwaters 
Table 1 Puffinus tenuirostris. Provisioning parameters of foraging trips of short and long duration [average $\pm 1 \mathrm{SD}$, (sample size), rangel

\begin{tabular}{|c|c|c|c|}
\hline & Short trips & Long trips & p-value for comparison \\
\hline Duration of foraging trips (d) & $\begin{array}{c}1.3 \pm 0.5(105) \\
1-3\end{array}$ & $\begin{array}{c}12.1 \pm 1.7(48) \\
9-17\end{array}$ & \\
\hline Meal mass $(g)$ & $\begin{array}{c}78.2 \pm 39.7(56) \\
10-185\end{array}$ & $\begin{array}{c}173.5 \pm 22.7(56) \\
135-205\end{array}$ & $<0.0001$ \\
\hline Adult body mass at arrival on land $(g)$ & $\begin{array}{c}652 \pm 56.2(20) \\
550-750\end{array}$ & $\begin{array}{c}744.8 \pm 55.6(29) \\
645-840\end{array}$ & $<0.001$ \\
\hline Adult body mass after meal delivery $(g)$ & $\begin{array}{c}570.0 \pm 38.9(52) \\
475-660\end{array}$ & $\begin{array}{c}589.4 \pm 40.1(48) \\
500-655\end{array}$ & $=0.02$ \\
\hline Body condition after meal delivery & $\begin{array}{c}-5.3 \pm 38.3(29) \\
-60.0-116.0\end{array}$ & $\begin{array}{c}-2.2 \pm 44.2(28) \\
-86.1-86.5\end{array}$ & $=0.770$ \\
\hline Change in adult body mass (g) & $\begin{array}{c}-17.4 \pm 27.3(27) \\
-55-30\end{array}$ & $\begin{array}{c}12.5 \pm 36.2(6) \\
-55-50\end{array}$ & $=0.029$ \\
\hline Body mass $(g)$ before a trip & $\begin{array}{c}595.4 \pm 41.5(45) \\
500-665\end{array}$ & $\begin{array}{c}568.6 \pm 39.8(29) \\
475-645\end{array}$ & $=0.007$ \\
\hline Body condition before a trip & $\begin{array}{c}17.2 \pm 40.7(25) \\
-50.0-116.0\end{array}$ & $\begin{array}{c}-13.0 \pm 32.9(15) \\
-45.0-59.0\end{array}$ & $=0.024$ \\
\hline
\end{tabular}
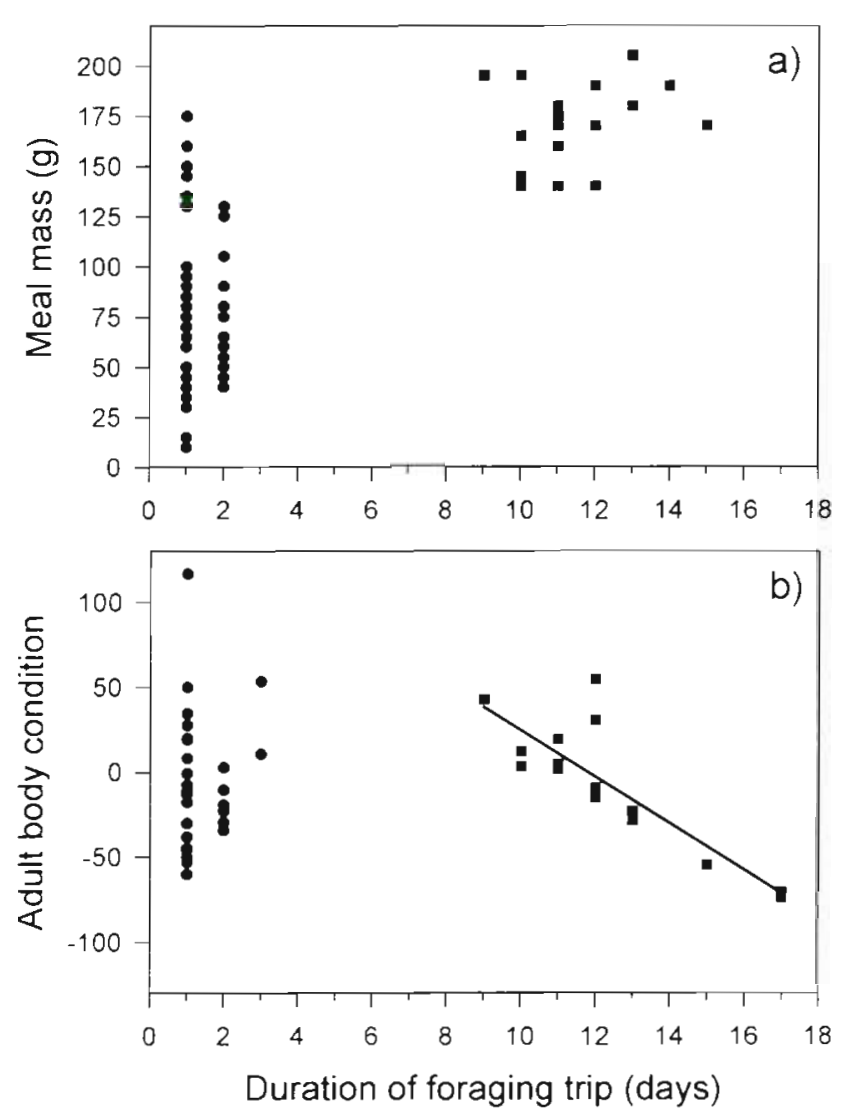

Fig. 4. Puffinus tenuirostris. Relationship between the duration of foraging trips and (a) the meal mass delivered to the chick, (b) the body condition of the adult next, with the change being negative after ST and positive after LT (Table 1).

Birds starting a LT were significantly lighter and in poorer condition than birds starting a ST (Table 1). For LT, the duration of the foraging trip was inversely related to the body condition of the adult $(r=-0.849$, $\mathrm{p}<0.001, \mathrm{n}=18$ ), whereas the body condition of adults after 1,2 and $3 \mathrm{~d}$ trips did not differ significantly $\left(F_{2,26}=\right.$ 1.49, $p=0.244$; Fig. 4 b). There was no significant relationship between the condition of the adult and the size of the meal delivered after a ST $(r=0.185, n=20$, $p>0.1)$ or after a LT $(r=0.120, n=19, p>0.1)$.

\section{Maximum diving depths and diet}

The maximum depths attained by short-tailed shearwaters were $13.0 \pm 7.3 \mathrm{~m}$ (range 3.9 to $30, \mathrm{n}=14$ ) during ST and $58.0 \pm 10.8 \mathrm{~m}$ (range 33.5 to $70.6, \mathrm{n}=8$ ) during LT $(t=1.1 .1, p<0.001)$. The stomach contents of adults were composed of a liquid fraction (32\% by mass) made of water and oil and a solid fraction (68\%) made of more or less digested prey items and of accumulated prey items such as squid beaks or fish otoliths. The 5 samples collected after a ST were quite similar. The bulk of the food comprised fish postlarvae $126 \%$ of the solid fraction) and Australian krill Nyctiphanes australis (74\%), which occurred in all the samples and together formed more than $99 \%$ of the total prey number (Table 2). Australian krill generally was hardly digested; both sexes were found, including adult females bearing eggs. Fish postlarvae were badly 
Table 2. Puffinus tenuirostris. Composition of the food delivered to chicks after short $(n=5)$ and long ( $n=17$ ) foraging trips of adult short-tailed shearwaters at Bruny Island, Tasmania. ST: short trips; LT long trips

\begin{tabular}{|c|c|c|c|c|c|c|c|c|}
\hline & \multicolumn{4}{|c|}{ Occurrence } & \multicolumn{4}{|c|}{ Numbers } \\
\hline & \multicolumn{2}{|c|}{$\mathrm{ST}$} & \multicolumn{2}{|c|}{ LT } & \multicolumn{2}{|c|}{ ST } & \multicolumn{2}{|c|}{$\mathrm{LT}$} \\
\hline & $\mathrm{n}$ & $\%$ & $\mathrm{n}$ & $\%$ & $\mathrm{n}$ & $\%$ & $\mathrm{n}$ & $\%$ \\
\hline \multicolumn{9}{|l|}{ Fish } \\
\hline \multicolumn{9}{|l|}{ Photichthyidae } \\
\hline Photichthys argenteus & 0 & 0 & 2 & 12 & 0 & 0 & 2 & $<0.1$ \\
\hline \multicolumn{9}{|l|}{ Myctophidae } \\
\hline Krefftichthys anderssoni & 0 & 0 & 3 & 18 & 0 & 0 & 7 & $<0.1$ \\
\hline Lampanyctus intricanus & 0 & 0 & 1 & 6 & 0 & 0 & 1 & $<0.1$ \\
\hline ?Lampadena notialis & 0 & 0 & 1 & 6 & 0 & 0 & 1 & $<0.1$ \\
\hline Unidentified myctophid & 0 & 0 & 1 & 6 & 0 & 0 & 1 & $<0.1$ \\
\hline Unidentified fish postlarvae & 5 & 100 & 15 & 88 & 485 & 3.5 & 2772 & 34.4 \\
\hline Unidentified fish & 0 & 0 & 7 & 41 & 0 & 0 & 34 & 0.4 \\
\hline \multicolumn{9}{|l|}{ Crustaceans } \\
\hline \multicolumn{9}{|l|}{ Isopoda } \\
\hline Flabellifera sp. & 1 & 20 & 0 & 0 & 2 & $<0.1$ & 0 & 0 \\
\hline \multicolumn{9}{|l|}{ Amphipoda } \\
\hline Themisto gaudichaudii & 2 & 40 & 13 & 76 & 4 & $<0.1$ & 298 & 3.7 \\
\hline Themisto australis & 4 & 80 & 1 & 6 & 16 & 0.1 & 1 & $<0.1$ \\
\hline Cyllopus magellanicus & 0 & 0 & 1 & 6 & 0 & 0 & 1 & $<0.1$ \\
\hline Hyperiidae sp. & 0 & 0 & 1 & 6 & 0 & 0 & 1 & $<0.1$ \\
\hline \multicolumn{9}{|l|}{ Euphausiacea } \\
\hline Euphausia vallentini & 0 & 0 & 6 & 35 & 0 & 0 & 3265 & 40.5 \\
\hline Euphausia sp. & 0 & 0 & 2 & 12 & 0 & 0 & 2 & $<0.1$ \\
\hline Nyctiphanes australis & 5 & 100 & 6 & 35 & 13125 & 95.8 & 1561 & 19.4 \\
\hline Thysanoessa gregaria & 3 & 60 & 7 & 41 & 70 & 0.5 & 32 & 0.4 \\
\hline Nematoscelis megalops & 0 & 0 & 3 & 18 & 0 & 0 & 74 & 0.9 \\
\hline \multicolumn{9}{|l|}{ Thoracica } \\
\hline Cyprid stage & 0 & 0 & 1 & 6 & 0 & 0 & 1 & $<0.1$ \\
\hline \multicolumn{9}{|l|}{ Reptantia } \\
\hline Brachyura, Megalopa larvae & 2 & 40 & 3 & 18 & 2 & $<0.1$ & 4 & $<0.1$ \\
\hline \multicolumn{9}{|l|}{ Squid } \\
\hline \multicolumn{9}{|l|}{ Onychoteuthidae } \\
\hline Moroteuthis ingens & 0 & 0 & 1 & 6 & 0 & 0 & 1 & $<0.1$ \\
\hline Kondakovia longimana & 0 & 0 & 1 & 6 & 0 & 0 & 1 & $<0.1$ \\
\hline Unidentified squids & 0 & 0 & 2 & 12 & 0 & 0 & 2 & $<0.1$ \\
\hline Stomach oil & $0^{\mathrm{a}}$ & 0 & 16 & 94 & - & - & - & - \\
\hline Accumulated items ${ }^{b}$ & 0 & 0 & 17 & 100 & - & - & - & - \\
\hline $\begin{array}{l}\text { aOnly traces in } 3 \text { samples } \\
\text { bInclude fish and squid lenses }\end{array}$ & 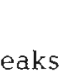 & & & & & & & \\
\hline
\end{tabular}

damaged, thus precluding identification to species. However, flesh and skin colour, skeletal remains, jaws and fish size (a few $\mathrm{cm}$ ) indicated that probably only 1 species was involved. There was no oil in the liquid fraction.

Unlike samples after ST, stomach contents collected after a LT contained accumulated items and variable amounts of an orange-coloured oil (mean value $12.0 \pm$ $12.7 \mathrm{ml}$, range: 0 to $55 \mathrm{ml}$ oil). Oil represented $44 \%$ of the liquid fraction, the remainder being water. The solid fraction was made up of several species of crustacean and fishes ( 18 and $82 \%$ by mass respectively). Twenty-one different taxa (only 7 in ST samples) were identified, including not only crustaceans and fish, but also squids (Table 2). By number, the diet was domi- nated by the sub-Antarctic krill Euphausia vallentini $(41 \%)$, followed by fish postlarvae $(34 \%)$ and Australian krill (19\%). Other common prey included the amphipod Themisto gaudichaudii (4\%) and the euphausiids Thysanoessa gregaria and Nematoscelis megalops $(<1 \%)$. Larger prey were also found, but in small numbers; they were mesopelagic fish and squid. Prey items, except Australian krill, were generally almost completely digested in LT samples. Accumulated lower beaks of cephalopods belonged to juveniles of 2 onychoteuthid squids, Kondakovia longimana $(\mathrm{n}=5)$ and Moroteuthis ingens $(\mathrm{n}=2)$, to Gonatus antarcticus and to 1 unidentified squid species. The accumulated eye lenses were larger than those of fish postlarvae and were probably of myctophid fish. 


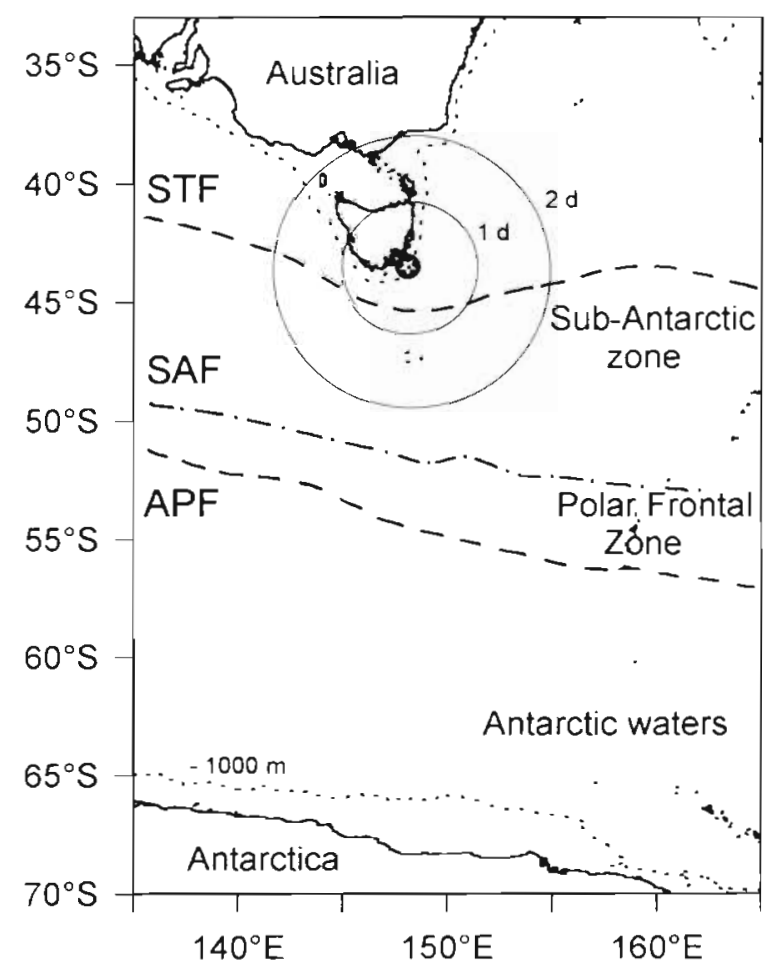

Fig. 5. The Southern Ocean between Tasmania and the Antarctic continent, showing the location of fronts (STF: subtropical front; SAF: sub-Antarctic front; APF: Antarctic Polar Front) and of water masses. Bruny Island, off southwestern Tasmania, is indicated by a star. Concentric circles indicate the maximum potential range of short-tailed shearwaters Puffinus tenuirostris from Bruny Island, during foraging trips of 1 and $2 \mathrm{~d}$

\section{Distribution of water masses and foraging ranges}

In March 1997 the sub-tropical front was just south of Bruny Island, southern Tasmania (Fig. 5). The subAntarctic front was $1000 \mathrm{~km}$ south of the island, the Antarctic Polar Front at $1200 \mathrm{~km}$ distance and the limit of the pack-ice at $2400 \mathrm{~km}$ (Fig. 5). During ST of $1 \mathrm{~d}$ short-tailed shearwaters have a potential foraging range of $300 \mathrm{~km}$ and are able to forage only in neritic waters and in oceanic waters of the sub-tropical frontal zone, whereas during trips of $2 \mathrm{~d}$ their $600 \mathrm{~km}$ maximum foraging range allows them to forage south of the sub-tropical front, but not to reach the sub-Antarctic front (Fig. 5). They need at least $5 \mathrm{~d}$ for the return trip to the Polar Front and Antarctic waters.

\section{Energy flows and foraging efficiency}

The energy delivered to the chick by each parent was calculated as $248 \mathrm{~kJ}$ after a ST and $1643 \mathrm{~kJ}$ after a $\mathrm{LT}$, giving an energy flow to the chick of $4.3 \mathrm{~W}\left(\mathrm{~J} \mathrm{~s}^{-1}\right)$ for ST and 3.1 W for LT. The net energy flow, given that the parents are making on average $2 \mathrm{ST}$ for $1 \mathrm{LT}$, is consequently $3.9 \mathrm{~W}$. Energy expended by the adult during the average ST (mass-specific daily energy expenditure $x$ body mass $x$ duration of trip) was calculated as $1091 \mathrm{~kJ}$ and during the average LT as $10351 \mathrm{~kJ}$ The increase in body mass after the average LT was equivalent to $278 \mathrm{~kJ}$, and the decrease after the average ST, to $516 \mathrm{~kJ}$. The combination of energy delivered to the chick, energy stored by the adults and energy expended for foraging, assuming that over the long term adults keep their body mass stable, gives a total food energy requirement of $1021 \mathrm{~kJ}$ for a ST and $15929 \mathrm{~kJ}$ for a LT, or a daily food intake of $773 \mathrm{~kJ} \mathrm{~d} \mathrm{~d}^{-1}$ during ST and $1316 \mathrm{~kJ} \mathrm{~d}^{-1}$ for LT.

\section{Prolactin and metabolite levels}

The level of plasma prolactin was high in March and there was no difference in prolactin levels of adult birds returning either from a ST or from a LT $(79.7 \pm$ $25.3 \mathrm{ng} \mathrm{ml}^{-1}, \mathrm{n}=6$ and $87.3 \pm 26.8, \mathrm{n}=9, t=0.63, \mathrm{p}=$ 0.542). When returning from a LT the level of prolactin was related to the body condition of the adult $\left(\mathrm{r}_{\mathrm{s}}=\right.$ 0.893, $p<0.02$ ), whereas there was no such relationship for ST $(p>0.1)$.

There was no difference between the levels of $\beta$-hydroxybutyrate or uric acid of adults returning from ST and LT $\left(1.3 \pm 0.9\right.$ and $0.9 \pm 0.4 \mathrm{mmol} \mathrm{l^{-1 }}$ respectively for $\beta$-hydroxybutyrate, Mann-Whitney $U$-test, $U=39, \mathrm{p}=$ $0.328 ; 0.4 \pm 0.1$ and $0.7 \pm 0.3 \mathrm{mmol} \mathrm{l}^{-1}$ respectively for uric acid, $U=16, \mathrm{p}=0.129$ ). Concentrations of uric acid were inversely related to the body condition of adults after LT $\left(r_{s}=-0.718, p<0.02\right)$ but not ST $(p>0.1)$.

For the birds rearing a chick in March, there was no significant influence of sex, of duration of foraging trip or of mass before the meal was delivered on the concentrations of prolactin, $\beta$-hydroxybutyrate or uric acid.

\section{DISCUSSION}

Based on measures of average feeding frequency and on diet samples, all previous studies on shorttailed shearwaters came to the conclusion that adults rearing chicks in Tasmania were relying mainly on neritic prey, especially Australian krill, caught in the vicinity of colonies (Bishop et al. 1983, Montague et al. 1986, Skira 1986). The short-tailed shearwaters present in large numbers in Antarctic waters south of Tasmania (Woehler et al. 1990) were presumed to be nonbreeding or immature birds, or failed breeders, although some birds may have been breeders (Kerry et 
al. 1983). Our study has shown that short-tailed shearwaters rely extensively on sub-Antarctic and even possibly Antarctic waters to provision the chick. This is made possible because they use a 2 -fold foraging strategy similar to that observed in other far-ranging petrels and albatrosses (Weimerskirch et al. 1994, 1997. Weimerskirch 1998). Although the average feeding frequency suggests that birds are performing foraging trips of $7.5 \mathrm{~d}$ on average, no bird was found performing trips of 4 to $8 \mathrm{~d}$. This is because the average chick feeding frequency cannot provide information on the duration of individual foraging trips, especially when their distribution is bimodal as in the case of birds using a 2 -fold strategy. During LT the average duration of $12 \mathrm{~d}$ allows short-tailed shearwaters from Tasmania to commute to distant feeding zones and thus accounts for the presence of short-tailed shearwaters in Antarctic waters. The analysis of prey items has allowed us to relate the duration of foraging trips to water masses, and thus to calculate the minimum distances between the breeding and feeding grounds.

\section{Feeding in Tasmanian waters}

During ST, adult short-tailed shearwaters mainly fed on fish postlarvae and on the Australian krill Nyctiphanes australis. Both the known distribution of their proy and the undigesied siate of the food brought back to the chicks indicate that during ST short-tailed shearwaters foraged over the continental shelf around Tasmania. Indeed $N$. australis and Themisto australis are restricted to the shallow neritic region around Tasmania (Hurley 1969, Blackburn 1980). N. australis is the major component of zooplankton biomass in that area, where other euphausiid species are rare or absent (Blackburn 1980، Ritz \& Hosie 1982). It plays a key role in the trophic web, being an important prey for many predators, including seabirds (O'Brien 1988, Young et al. 1993).

Our finding that Australian krill and small fish are major components of the food of short-tailed shearwaters during the breeding season agrees well with previous studies on colonies both in Tasmania (Morgan \& Ritz 1982, Bishop et al. 1983, Skira 1986) and in southern Australia (Montague et al. 1986). Visual observations of flocks of foraging short-tailed shearwaters are common in inshore waters of Tasmania, including off Bruny Island (authors' unpubl. data). Birds were probably feeding on surface or near-surface schools of $N$. australis, which are known to occur there not only at night but also during daylight (O'Brien 1988). Shearwaters therefore feed on epipelagic prey located in shallow waters, which thus explains the moderate maximum diving depths $(4$ to $30 \mathrm{~m}$ ) reached by the birds during ST. This feeding behaviour appears to be one of the main foraging techniques of short-tailed shearwaters since it has been recently shown that they also prey upon near-surface swarms of euphausids or upon euphausids trapped in water shallower than $40 \mathrm{~m}$ on their wintering ground, in neritic waters of the north Pacific (Hunt et al. 1996).

Although short-tailed shearwaters feed in large numbers in coastal and neritic waters (Marchant \& Higgins 1990, Woehler et al. 1990), the observation that they also have to travel to distant Antarctic waters to feed their chick suggests that the availability of Australian krill and other neritic prey is probably unable to sustain the entire breeding population during this period of the year. It only allows short-tailed shearwaters to substantially increase the energy flow to the chick. Populations of short-tailed shearwaters are huge, with an estimated 23 million breeding birds (Skira et al. 1985). Competition in coastal and neritic waters is likely to be extremely high in these waters, which are limited in surface area. The 2-fold strategy would reduce competition, as at a given time in March it is estimated that only $17 \%$ of the breeding birds are making ST, i.e. foraging in neritic and coastal waters.

\section{Feeding in the Southern Ocean while nesting in Tasmania}

Stomach contents collected from birds returning from LT contained many different prey items, including those found in ST samples. The mixing of thoroughly and partially digested prey items suggests that LT samples represent different prey taken at different times from different water masses. The known biogeography of crustaceans, fish and squid indicates that some prey were caught in neritic waters (Nyctiphanes australis) and others in oceanic waters (the euphausiids Thysanoessa gregaria and Nematoscelis megalops, and the fishes Photichthys argenteus, Lampanyctus intricarius and Lampadena notialis) off Tasmania (Lomakina 1966, Blackburn 1980, Terazaki \& Wada 1986, Young et al. 1996). Thus birds probably feed during the return journey on the Tasmanian shelf, as indicated by the presence of undigested neritic speciessuch as the Australian krill - in the same meal as more thoroughly digested prey of more distant origin. Some prey were taken further south. Euphausia vallentini occurs mainly in the coldest waters of the 'notal region' (Lomakina 1966), which corresponds now to the Polar Frontal Zone (between the sub-Antarctic Front and the Antarctic Polar Front; Fig. 5). Krefftichthys anderssoni is one of the most abundant myctophid fish in the range from the Polar Frontal Zone to the south of the Antarctic Polar Front (Sabourenkov 1991), and the 
squid Kondakovia longimana is known south of the Antarctic Polar Front (Lubimova 1985). Our data therefore show clearly that during LT, short-tailed shearwaters forage in pelagic waters south of Tasmania, where they commonly reach the Polar Frontal Zone and Antarctic waters south of the Antarctic Polar Front, which was at $53^{\circ} \mathrm{S}$ in that part of the Pacific Ocean at the time of our study (Rintoul et al. 1997). This finding agrees with the hypothesis that short-tailed shearwaters are able to forage in Antarctic waters during the breeding season (Naarding 1980, Weimerskirch 1998), and also with the direct observations of flocks of birds feeding on Euphausia superba in Antarctica during the chick-rearing period (Kerry et al. 1983, Woehler et al. 1990, Veit \& Hunt 1991). Surprisingly, fresh remains of notal and Antarctic prey were not previously identified in food samples collected in breeding colonies (Montague et al. 1986, Skira 1986), but some accumulated squid beaks belonging to Southern Ocean species were found in stomachs of birds of unknown breeding status (Skira 1986).

Another important finding of this study is that stomach oil occurred consistently in LT samples, but not in ST samples. The orange colour of the oil clearly indicates its crustacean origin. Bishop et al. (1983), using lipid analysis, suggested that chick proventricular oil was derived mainly from Nyctiphanes australis. Our data do not agree with that hypothesis since at least some of the chick oil comes directly from adult oil given to the chicks after a long trip. Moreover, shearwater oil has a large content of wax esters (Cheah \& Hansen 1970, Bishop et al. 1983), which, contrary to the finding of Bishop et al. (1983), do not occur in the lipids of $N$. australis (Cheah \& Hansen 1970. Virtue et al. 1995). Cheah \& Hansen (1970) also found the carotenoid pigments of shearwater oil to differ from those of Australian krill. None of the other crustaceans (Themisto gaudichaudii, Thysanoessa gregaria, Nematoscelis megalops, Euphausia vallentini and $E$. superba) eaten by short-tailed shearwaters contain large amounts of wax esters (Clarke 1984, Attwood \& Hearshaw 1992). The dietary origin of the oil therefore remains unknown, but consumption of the Antarctic euphausiids Thysanoessa vicina and $T$ macrura and/or of large calanoid copepods (Clarke 1984, Attwood \& Hearshaw 1992) could explain the high quantities of wax esters found in the shearwater oil.

Short-tailed shearwaters rely extensively on diving for feeding, as their major feeding techniques are pursuit diving from the surface, plunging from above the surface and, to a lesser extent, seizing prey at the surface and hydroplaning (Hunt et al. 1996, authors' pers. obs.). The maximum depths attained during LT are similar to those reached by sooty shearwaters (Weimerskirch \& Sagar 1996) and appear remarkable for skilled flying birds. In the Polar Frontal Zone and in Antarctic waters, myctophids and krill undertake vertical migration, coming closer to the surface at night (Hulley 1990, Lomakina 1966). Myctophid fish and krill are rarely available at the surface during daytime and are thus likely to be caught during deep diving during the day, as these birds probably do not dive deep at night, but further information on the diving behaviour of these shearwaters is needed to confirm this hypothesis. Also the accuracy of the capillary tubes in measuring maximum depths decreases with increasing time (Burger \& Wilson 1988).

The estimated daily rates of food intake during LT are twice those recorded during $\mathrm{ST}$, indicating that sub-Antarctic and Antarctic waters are twice as profitable for this shearwater as neritic or sub-tropical oceanic waters. The actual difference is likely to be even greater, as during LT the commuting part of the trip to feeding zones has a lower yield than the period when birds are feeding. Therefore food availability could be at least 3 times higher in southern waters compared to Tasmanian neritic waters. Overall Antarctic waters and the Polar Frontal Zone are known to be more productive than sub-tropical waters (Comiso et al. 1993).

\section{Foraging decisions}

The 2-fold foraging strategy allows short-tailed shearwaters to rely heavily on food resources located at a distance of over $1000 \mathrm{~km}$ to rear a chick in Tasmania. This would not be possible if birds were only performing ST, because adults would lose body condition rapidly, or if birds were only performing $L T$, because the energy flow to the chick would be insufficient for its growth. The strategy allows birds to rely mainly on productive Antarctic and sub-Antarctic waters, but at some stages birds have to decide to forage in a zone of lower profitability by undertaking ST. The decision to forage on ST or on LT, i.e. to increase the energy flow to the chick or to restore its body condition, appears not to be related to the condition of the chick, but to that of the adult. The decision could be under the control of prolactin, a hormone associated with parental care (Phillips et al. 1985). In the middle of the chick rearing period in March, prolactin levels remain high and similar to levels measured at hatching (authors' unpubl. results). Prolactin levels are related to adult body condition in birds returning from a LT. Good body condition after a LT allows birds to invest in the production of offspring and to perform ST to increase the rate of energy flow to the chick. Low levels of prolactin due to poor body condition induce birds to start a LT to recuperate. Here, prolactin could play the role of initiator of 
parental behaviour, with the possible existence of a threshold value of body condition (Weimerskirch 1998) as the proximal factor. In other petrels, desertion or breeding onset has been shown to be related to threshold levels of body condition (Chaurand \& Weimerskirch 1994, Chastel et al. 1995). Interestingly, in king penguins prolactin levels drop during chick rearing, when the mass of adults enter into a phase of body reserve depletion, i.e. when adults are close to desertion (Cherel et al. 1994).

Levels of uric acid are indicative of protein utilisation (Cherel et al. 1987), and in petrels higher levels probably imply the use of exogenous food rather than endogenous protein, whereas higher levels of $\beta$-hydroxybutyrate are indicative of the use of lipids, either endogenous, namely body reserves, or exogenous, as would likely be the case for stomach oil. The inverse relationship between body condition and the level of uric acid after LT indicates that birds that have stored large quantities of body reserves are no longer digesting food, possibly because they keep the food caught to deliver it to the chick. Good body condition could therefore influence the decision either to transform food into body reserves or to keep it to provision the chick, when a threshold value of body condition is attained. The optimal strategy could be first to rebuild body reserves and, when the threshold value is attained, to stop digestion and store food for the chick. Conflicts beiween digestion and delaying gastric emptying (Wilson et al. 1989) or between self-feeding and storing food for the chick should therefore be regarded as a trade-off between the production of offspring and future survival (Stearns 1992).

Decisions to invest in offspring production or survival are also constrained by the availability of food and the time spent foraging per unit of time on the feeding grounds. In short-tailed shearwaters the yield of LT declines with the duration of the foraging trip, as indicated by the inverse relationship between body condition and time spent foraging. It indicates that spending more time foraging than average is the result of poor foraging success and that only foraging trips of 9 to 12 d have high profitability. Similar results have been found in 2 other petrels during incubation (Chaurand \& Weimerskirch 1994, Tveraa et al. 1997), but they differ from wandering albatrosses, for which foraging time is positively correlated with adult mass increase during LT for incubation and chick rearing periods (Weimerskirch 1995, Weimerskirch et al. 1997). These differences are probably related to the foraging strategy and to the predictability of prey capture. Whereas the 3 petrels considered are likely to commute to distant specific foraging sectors with a predictable location but where profitability may be variable, wandering albatrosses follow long looping routes where variable likelihoods of prey capture are probably less locality-specific (see Weimerskirch 1997). Spending more time foraging results in higher prey capture in the albatross, whereas it could have opposite results with the 3 petrels considered.

\section{Consequences of the two-fold strategy}

Hatching was highly synchronised in short-tailed shearwaters, with $80 \%$ of hatching occurring within $6 \mathrm{~d}$, as has also been found during other seasons (Serventy 1967, Oka 1989). Like Oka et al. (1987) we found that average mass growth curve of chicks follows a cycle with a periodicity of about $16 \mathrm{~d}$ (Fig. 1b). The cycle is the result of the cyclic attendance of the nest by parents following a periodicity of about $16 \mathrm{~d}$ (Fig. 1c). In our study, lunar phase during the peaks is different from that observed in the previous study, indicating that phase of the moon was probably not responsible for the periodicity of the visits as previously suggested (Oka et al. 1987). Since the average provisioning strategy is to perform 1 LT of $12 \mathrm{~d}$ followed by 2 ST of $1.3 \mathrm{~d}$, the result is a cycle of about $14.6 \mathrm{~d}$, which is nearly $16 \mathrm{~d}$. Thus the cyclic attendance of nests by short-tailed shearwaters is the result of a 2 -fold feeding strategy as suggested by Weimerskirch (1998) for sooty shearwaters. Indeed as chick hatching is highly sunchronised, if birds retain the cycle of alternation through the chick rearing period, peaks of attendance would occur with regular cyclicity when most birds are returning from LT (see Richdale 1963, Weimerskirch 1998).

Just after hatching, birds probably visit their chick every day (see also Hamer et al. 1997) and are therefore performing only ST. Thereafter feeding frequency decreases continuously throughout the chick rearing period (Naarding 1980, but see Hamer et al. 1997). During our study in March chicks were fed infrequently, and the values obtained in our study are similar to those obtained by Naarding (1980) for a similar period but a different year. The body mass of chicks reaches a peak while their growth rate begins to slow down (Henstridge \& Tweedie 1984, Oka 1989), probably because the parents are providing less energy. The sinusoidal pattern of growth in mass throughout the chick rearing period (Oka et al. 1987) suggests that short-tailed shearwaters use a 2-fold strategy throughout the season. Because feeding frequency declines continuously as the season progresses they could be spending more and more time on LT, either through an increase in the duration of LT or through a decrease in the frequency of ST, but further studies are necessary to investigate this.

Coincident with the low provisioning rate in March, the condition of adults tends to deteriorate, as also 
indicated by the general decline in adult body mass through the chick rearing period measured for another season (Lill \& Baldwin 1983). This suggests that feeding condition deteriorates in March. Information on the main prey caught during ST, the Australian krill, indicates that its abundance only declines from April, although differences may occur between years (Young et al, 1993). The worsening of feeding conditions may therefore be attributable to the food supply during LT in Antarctic waters rather than to the food caught during ST, and indicates that food availability there probably declines as the nesting season progresses.

\section{Conclusion}

The short-tailed shearwater is the petrel species with the longest foraging trips during chick rearing for any species of albatross or petrel studied so far (Weimerskirch et al. 1994, 1995, 1997, Weimerskirch 1997. 1998), probably because the only profitable food resource allowing chick production is the most remote from the breeding grounds. To be able to exploit such a distant manine resource to rear a chick, several behavioural and physiological adaptations have been selected for in these species. These adaptations allow birds to adjust breeding effort, as a trade-off between survival and the production of offspring, to the marine environment. Knowledge of the marine environment and its variability and predictability is therefore essential for linking foraging behaviour and allocation processes (Boggs 1992) and understanding the evolution of the extreme life-history parameters of Procellariiformes.

Acknowledgements. This study was conducted under permit no. FA96188 from the Animal Ethics Committee of the Tasmanian Parks and Wildlife Service. The study would have not been possible without the help of Philippe Borsa. We thank the Parks and Wildlife Service for support, especially Nigel Brothers for making this study possible, Irynej Skira for extensive help with setting up the study on Bruny Island and Rosemary Gales. Renaud Weimerskirch helped us with the field study. Prof. G. L. Hunt and Dr R. Wilson gave helpful comments on the manuscript. Dr Stephen Hall improved the English, Colette Trouve helped with the analysis of diet samples and André Lacroix conducted the biochemical analysis.

\section{LITERATURE CITED}

Ashmole NP (1971) Seabird ecology and the marine environment. In: Farner DS, King JR (eds) Avian biology, Vol 1 Academic Press, London, p 223-286

Attwood CG. Hearshaw KD (1992) Lipid content and composition of sub-Antarctic euphausiids and copepods from the Prince Edward Islands. S Afr J Antarct Res 22:3-13

Baker A de C, Boden BP, Brinton E (1990) A practical guide to the euphausiids of the world. Natural History Museum Publications, London
Birt-Friesen VL, Montevecchi WA, Cairns DK, Macko SA (1989) Activity-specific metabolic rates of free-living northern gannet and other seabirds. Ecology 70:357-367

Bishop DG, Ritz DA, Hosie GW, Kenrick JR (1983) Fatty acid composition of the lipids of Puffinus tenuirostris (Temminck) in relation to its diet. J Exp Mar Biol Ecol 71:17-26

Blackburn M (1980) Observations on the distribution of $\mathrm{NyC}^{-}$ tiphanes australis Sars (Crustacea, Euphausiacea) in Australian waters. CSIRO Division of Fisheries and Oceanography, Melbourne, Report 119:1-10

Boggs CL (1992) Resource allocation: exploring connections between foraging and life history. Funct Ecol 6:508-518.

Burger A, Wilson RP (1988) Capillary-tube depth gauges for diving animals: an assessment of their accuracy and applicability. J Field Ornithol 59:345-354.

Chastel O, Weimerskirch $H_{1}$ Jouventin P (1995) Body condition and seabird reproductive performance: a study of three petrel species. Ecology 76:2240-2246

Chaurand $T$, Weimerskirch $H$ (1994) Incubation routine, body mass regulation and egg-neglect in the blue petrel Halobaena caerulea. Ibis 136:285-290

Cheah CC. Hansen IA (1970) Wax esters in the stomach oil of petrels. Int $\mathrm{J}$ Biochem 1:198-202

Cherel Y, Mauget R, Lacroix A, Gilles J (1994) Seasonal and fasting related changes in circulating gonadal steroids and prolactin in king penguins, Aptenodytes patagonicus. Physiol Zool 67:1.154-1173

Cherel Y, Ridoux V (1992) Prey species and nutritive value of food fed during summer to king penguin Aptenodytes patagonica chicks at Possession Island, Crozet islands. Ibis 134:118-127

Cherel Y, Stahl JC, Le Maho Y (1987) Ecology and physiology of fasting in king penguin chicks. Auk 104:254-262

Clarke A (1984) The lipid content and composition of some Antarctic macrozooplankton. Br Antarct Surv Bull 63: $57-70$

Clarke MR (1986) A handbook for the identification of cephalopod beaks. Clarendon Press, Oxford

Clarke MR, Prince PA (1980) Chemical composition and calorific value of food fed to mollymawk chicks Diomedea melanophris and D. chrysostoma a.t Bird Island, South Georgia. Ibis 122:488-494

Comiso JC, McClain CR, Sullivan CW, Ryan JP, Leonard CL (1993) Coastal zone color scanner pigment concentrations in the southern ocean and relationship to geophysical surface features. J Geophys Res 98:2419-2451

Croxall JP, Ricketts C, Prince PA (1985) Impact of seabirds on the marine resources, especially krill, of South Georgia waters. In: Whittow GC, Rahn $\mathrm{H}$ (eds) Seabirds energetics. Plenum, New York, p 285-318

Freeman S, Jackson WM (1990) Univariate metrics are not adequate to measure avian body size. Auk 107:69-74

Groscolas R, Schreiber L, Morin F (1991) The use of tritiated water to determine protein and lipid utilisation in fasting birds: a validation study in incubating great-winged petrels Pterodroma macroptera. Physiol Zool 64: $1217-1233$

Hamer KC, Nicholson LW, Hill JK, Wooller RD, Bradley JS (1997) Nestling obesity in procellariiform seabirds: temporal and stochastic variation in provisioning and growth of short-tailed shearwaters Puffinus tenuirostris. Oecologia 1.14:4-11

Henstridge JD. Tweedie RL (1984) A model for the growth pattern of mutton birds. Biometrics 40:917-925

Hulley PA (1990) Family Myctophidae. In: Gon O, Heemstra PC (eds) Fishes of the Southern Ocean. Smith Inst Ichthyology, Grahamstown, p 146-178 
Hunt GL, Coyle KO, Hoffman S, Decker MB, Flint E (1996) Foraging ecology of short-tailed shearwaters near the Pribilof Islands, Bering Sea. Mar Ecol Prog Ser 141:1-11

Hurley DE (1969) Amphipoda Hyperiidea. Antarct Map Folio Ser 11:32-34

Jackson S (1986) Assimilation efficiency of white-chinned petrel (Procellaria aequinoctialis) fed different preys. Comp Biochem Physiol 85A:301-303

Kerry KR, Horne RSC, Dorward DF (1983) Records of the short-tailed shearwater Puffinus tenuirostris in Antarctic waters. Emu 83:35-37

Lill A, Baldwin J (1983) Weight changes and the mode of depot fat accumulation in migratory short-tailed shearwaters. Aust J Zool 31:891-902

Lomakina NB (1966) The euphausiid fauna of the Antarctic and notal regions. In: Andriashev A.P, Ushakov PV (eds) Biological reports of the Soviet Antarctic expedition 1955-58, israël Programme for Scientific Translations, Jerusalem, p 260-342

Lubimova TG (1985) Results of Soviet investigations of the distribution and ecology of pelagic squids (Oegopsida) in the Southern Ocean. CCAMLR Sel Sci Pap 1985 $79-111$

Lutjerharms JRE, Valentine HR (1984) Southern Ocean thermal fronts south of Africa. Deep Sea Res 31:1461-1475

Marchant S, Higgins PJ (1990) Handbook of Australian, New Zealand and Antarctic birds. Oxford University Press. Melbourne

Montague TL, Cullen JM, Fitzherbert K (1986) The diet of the short-tailed shearwater Puffinus tenuirostris during its breeding season. Emu 86:207-213

Morgan WL, Ritz DA (1982) Comparison of the feeding apparatus in the muttonbird, Puffinus tenuirostris (Temminck) and the fairy prion, Pachyptila turtur (Kuhl) in relation to the capturie of the krili, Nyciiphanes austraüs Sars. J Exp Mar Biol Ecol 59:61-75

Naarding JA (1980) Study of the short-tailed shearwater Puffinus tenuirostris in Tasmania. National Parks and Wildlife Service, Tasmania

O'Brien DP (1988) Surface schooling behaviour of the coastal krill Nyctiphanes australis (Crustacea: Euphausiacea) off Tasmania, Australia. Mar Ecol Prog Ser 42:219-233

Oka $N$ (1989) Chick growth and development of the shorttailed shearwater Puffinus tenuirostris in Tasmania. J Yamashina Inst Ornithol 21:193-207

Oka N, Maruyama N, Skira I (1987) Chick growth and mortality of short-tailed shearwaters in comparison with sooty shearwaters, as possible index of fluctuations of Australian krill abundance. Proc Nat Inst Polar Res 1:166-174

Pennycuick CJ (1981) The flight of petrels and albatrosses (Procellariiformes), observed in South Georgia and its vicinity. Phil Trans R Soc Lond B300:75-106

Pennycuick CJ (1989) Bird flight performance: a practical calculation manual. Oxford University Press, Oxford

Phillips JG, Butler PJ, Sharp PJ (1985) Physiological strategies in avian biology. Blackie, Glasgow

Reynolds RW, Smith TM (1994) Improved global sea-surface temperature analyses. J Clim 7:929-948

Richdale LE (1963) Biology of the sooty shearwater Puffinus griseus. Proc Zool Soc Lond 141:1-117

Ricklefs RE (1990) Seabird life histories and the marine environment: some speculations. Colon Waterbirds 13:1-6

Ricklefs RE, White SC, Cullen J (1980) Energetics of postnatal growth in Leach's storm petrel. Auk 97:566-575

Rintoul SR, Donguy JR, Roemmich DH (1997) Seasonal evolution of upper ocean thermal structure between Tasmania and Antarctica. Deep Sea Res 44:1185-1202
Ritz DA, Hosie GW (1982) Praduction of the euphausiid NyCtiphanes australis in Storm Bay, south-eastern Tasmania. Mar Biol 68:103-108

Sabourenkov EN (1991) Mesopelagic fish of the Southern Ocean-summary results of recent Soviet studies. CCAMLR Sel Sci Pap 1990:433-457

Serventy DL (1967) Aspects of the population ecology of the short-tailed shearwater Puffinus tenuirostris. Proc XIV Int Ornithol Congr, p 165-190

Skira IJ (1986) Food of the short-tailed shearwater, Puffinus tenuirostris, in Tasmania. Aust Wildl Res 13:481-488

Skira IJ, Wapstra JE, Towney GN. Naarding JA (1985) Conservation of the short-tailed shearwater Puffinus tenuirostris in Tasmania, Australia. Biol Conserv 37:225-235

Smale MJ, Watson G. Hecht T (1995) Otolith atlas of Southern African marine fishes. Ichthyological Monographs, Vol 1 JLB Smith Institute of Ichthyology, Grahamstown

Stearns SC (1992) The evolution of life histories. Oxford University Press, Oxford

Terazaki M, Wada M (1986) Euphausiids collected from the Australian sector of the Southern Ocean during the Biomass SIBEX cruise (KH-83-4). Mem Natl Inst Polar Res Spec Issue 40:97-109

Tveraa T, Lorentsen SH, Saether BE (1997) Regulation of foraging trips and costs of incubation shifts in the Antarctic petrel (Thalassoica antarctica). Behav Ecol 8:465-469

Veit RR, Hunt GL (1991) Broadscale density and aggregation of pelagic birds from a circumnavigational survey of the Antarctic Ocean. Auk 108:790-800

Vinogradov ME, Volkov AF, Semenova TN (1996) Hyperiid amphipods (Amphipoda, Hyperiidea) of the world oceans. Science Publishers, Lebanon

Virtue P, Johannes RE, Nichols PD, Young JW (1995) Biochemical composition of Nyctiphanes australis and its possible use as an aquaculture feed source: lipids, pigments and fluoride content. Mar Biol 122:121-128

Warham J (1996) The behaviour, population biology and physiology of the petrels. Academic Press, San Diego

Warham J, Watts R, Dainty RJ (1976) The composition, energy content and functions of stomach oil of petrels (order Procellariiformes). J Exp Mar Biol Ecol 23:1-13

Weimerskirch $H$ (1995) Regulation of foraging trips and incubation routine in male and female wandering albatrosses. Oecologia 102:37-43

Weimerskirch H (1997) Foraging strategies of southern albatrosses and their relationship with fisheries. In: Robertson G, Gales R (eds) Albatross biology and conservation. Surrey Beatty \& Sons, Sydney, p 168-179

Weimerskirch $\mathrm{H}$ (1998) How can a pelagic seabird provision its chick when relying on a distant resource? Cyclic attendance, foraging decision and body condition in sooty shearwaters. J Anim Ecol 67:99-109

Weimerskirch $\mathrm{H}$, Chastel $\mathrm{O}$, Chaurand $\mathrm{T}$, Ackerman L, Hindermeyer X, Judas J (1994) Alternate long and short foraging trips in pelagic seabird parents. Anim Behav 47 : $472-476$

Weimerskirch $H$, Cherel $Y$, Cuénot Chaillet $F$, Ridoux V (1997) Alternative foraging strategies and resource allocation by male and female wandering albatrosses. Ecology 78:2051-2063

Weimerskirch H, Sagar P (1996) Diving depths in sooty shearwaters Puffinus griseus. Ibis 138:786-788

Wilkinson L (1996) SYSTAT 6.0 for Windows: statistics. SPSS Inc, Chicago

Wilson RP (1984) An improved stomach pump for penguins and other seabirds. J Field Ornithol 55:109-112

Wilson RP, Ryan PG, Wilson MP (1989) Sharing food in the 
stomachs of seabirds between adults and chicks - a case for delayed gastric emptying. Comp Biochem Physiol 94 A: $461-466$

Woehler EJ, Hodges CL, Watts DJ (1990) An atlas of the pelagic distribution and abundance of seabirds in the southern Indian Ocean, 1981 to 1990. ANARE Research Notes 77, Antarctic Division, Kingston

Young JW, Jordan AR, Bobbi C, Johannes RE, Haskard K.

Editorial responsibility: Otto Kinne (Editor), Oldendorf/Luhe, Germany
Pullen G (1993) Seasonal and interannual variability in krill (Nyctiphanes australis) stocks and their relationship to the fishery for jack mackerel (Trachurus declivis) off eastern Tasmania, Australia. Mar Biol 116:9-18

Young JW, Lamb TD, Bradford RW (1996) Distribution and community structure of midwater fishes in relation to the subtropical convergence off eastern Tasmania, Australia. Mar Biol 126:571-584

Submitted: January 26, 1998; Accepted: April 16, 1998 Proofs received from author(s): June 2, 1998 